\title{
Optimum usage of Using Metakaolin and Quarry Dust in High Performance Concrete
}

\author{
G.R.Vijay shankar*, Dr.D.Suji** \\ *(Assistant professor - Department of Civil Engineering, Karpagam University. Coimbatore-641 021, \\ Tamilnadu, India \\ ** (Dean-Department of Civil Engineering, R.V.S. college of Engineering and Technology .Coimbatore-641 \\ 402, Tamilnadu, India,
}

\begin{abstract}
Today's environmental problems are more and more important. The industrial area produces lots of waste materials .One of the most useful ways to solve these problems is the consumption of these waste materials in concrete. The quarry dust is an economic and waste material of rock and alternative to the river sand. Conventional concrete is the most extensively used construction material world wide, both in moderately and strongly aggressive environments. High performance concrete (HPC) appears to be a better choice for stronger and durable structures. These needs have made the engineers look for an appropriate technology for improving the performance of concrete. In this paper describes the studies made to ascertain the properties of HPC M40 grade concrete by using Metakaolin as partial cement replacement and Quarry dust as partial fine aggregate replacement to determine the compressive and tensile strength experimentally.
\end{abstract}

Keywords: - Quarry dust, metakaolin, super plasticizers, M40 concrete, strength, results.

\section{INTRODUCTION}

Concrete despite its inherent deficiencies is the most extensively used material world wide for the construction of large infrastructural facilities. In the past there has been considerable attention for improving the properties of concrete with respect to strength and durability, especially in aggressive environments. In the foreseeable future, there seems to be no alternative to concrete as a construction material. There has been substantial advancement during the last 100 years in the science and practice of concrete technology, out of which the last 30 years have seen considerable progress, Although the compressive strength of concrete has been historically and steadily increasing the commercial potential of high strength concrete became evident for the columns of high rise buildings in the 1970"s in the United States. There are other equally important criteria for the characterization of concrete such as durability, workability and toughness. For example in prestressed concrete bridges the concrete should have not only high strength but also reduced shrinkage and creep. For bridges, offshore structures, highway and airport pavements and machine foundations, concrete should possess high fatigue strength. For nuclear containers exposed to very high temperatures, the concrete must have a high resistance to thermal cracking. Therefore considerable attention has been paid to the research and development of high performance concrete (HPC) with a view to enhance the potential of the material to build for the service life of about 100 years instead of customary 40 to 50 years and to provide satisfactory performance under different aggressive environments.

\section{MATERIALS AND METHODS}

\subsection{Materials Used:}

The materials used include Ordinary Portland Cement (43 Grade), metakaolin, super plasticizers, quarry-dust, river sand, coarse aggregate and water. Cement, Metakaolin, super plasticizers, Quarry dust, River sand and coarse aggregate are tested for their physical characteristics as per the relevant standards. The results are presented in Table 1, 2, 3 and 4.

Table 1. Physical Characteristics of Cement

\begin{tabular}{|l|c|}
\hline \multicolumn{1}{|c|}{ Characteristics } & Cement \\
\hline Specific gravity & 3.15 \\
\hline Standard Consistency (\%) & 31.5 \\
\hline Initial Setting Time (minutes) & 140 \\
\hline Final Setting Time (minutes) & 480 \\
\hline Fineness (\%) & 4 \\
\hline
\end{tabular}


Table 2. Physical Characteristics of Metakaolin

\begin{tabular}{|l|c|}
\hline \multicolumn{1}{|c|}{ Test Particulars } & Results obtained \\
\hline Average particle size $(\mu \mathrm{m})$ & 1.5 \\
\hline Contact surface area $(\mathrm{m} 2 / \mathrm{gm})$ & 15 \\
\hline Pozzolan Reactivity $(\mathrm{mg} \mathrm{Ca}(\mathrm{OH}) 2 / \mathrm{gm})$ & 1050 \\
\hline Specific Gravity & 2.5 \\
\hline Bulk density $(\mathrm{kg} / \mathrm{m} 3)$ & $300 \pm 30$ \\
\hline Brightness & $80 \pm 2$ Off-white \\
\hline Physical Form & Powder \\
\hline
\end{tabular}

Table 3. Physical and Chemical Characteristics of Super Plasticizers

\begin{tabular}{|l|l|}
\hline \multicolumn{1}{|c|}{ Particulars } & \multicolumn{1}{c|}{ Super slump-Pn } \\
\hline Usage & High-range water reducing type super plasticizer \\
\hline Classification & Polycarbixylate based super plasticizer \\
\hline Appearance & Light brown liquid \\
\hline Solid Content & Min. $40 \%$ \\
\hline Viscosity $\left(25^{\circ} \mathrm{C}\right)$ & Max. $1000 \mathrm{cPS}$ \\
\hline Density & $1.10-1.20 \mathrm{mg} / 1$ \\
\hline $\mathrm{pH}$ & $4.0-7.5$ \\
\hline
\end{tabular}

Table 4. Physical Characteristics of Fine Aggregate, Quarry dust and Coarse Aggregate

\begin{tabular}{|l|c|c|c|}
\hline \multicolumn{1}{|c|}{ Characteristics } & River Sand & Quarry Dust & Coarse Aggregate (20 mm) \\
\hline Specific Gravity & 2.09 & 2.36 & 3.06 \\
\hline Grading Zone & Zone II & - & Zone III \\
\hline
\end{tabular}

\subsection{Mixture proportioning:}

Trial mixtures were prepared to obtain target strength of $40 \mathrm{MPa}$ at 28 days along with $\mathrm{w} / \mathrm{b}$ ratio is 0.34 . The detailed mixture proportions for the study are presented in Table 5.

Table 5. Concrete mixture proportions - based on IS 10262-2009 method

\begin{tabular}{|c|c|c|c|c|c|c|}
\hline $\begin{array}{c}\text { Cement } \\
\left(\mathbf{k g} / \mathbf{m}^{\mathbf{3}}\right)\end{array}$ & $\begin{array}{c}\text { Metakaolin } \\
\left(\mathbf{k g} / \mathbf{m}^{\mathbf{3}}\right) \\
\mathbf{F o r ~ 5 \%}\end{array}$ & $\begin{array}{c}\text { Fine } \\
\text { aggregate } \\
\left(\mathbf{k g} / \mathbf{m}^{\mathbf{3}}\right)\end{array}$ & $\begin{array}{c}\text { Coarse } \\
\text { aggregate } \\
\left(\mathbf{k g} / \mathbf{m}^{\mathbf{3}}\right)\end{array}$ & $\begin{array}{c}\text { Quarry } \\
\text { Dust } \\
\left(\mathbf{k g} / \mathbf{m}^{\mathbf{3}}\right)\end{array}$ & $\begin{array}{c}\text { Water } \\
\left(\mathbf{k g} / \mathbf{m}^{\mathbf{3}}\right)\end{array}$ & $\begin{array}{c}\text { Super } \\
\text { Plasticizers } \\
\left(\mathbf{k g} / \mathbf{m}^{\mathbf{3}}\right)\end{array}$ \\
\hline 411.73 & 21.67 & 462.44 & 1226.389 & 174.06 & 157.6 & 8.27 \\
\hline
\end{tabular}

\subsection{Compressive strength test:}

The prepared cubes are cured for 7 days, 14 days , 28 days 56days ,90 days and 120 days. At the end of curing period, the cube were placed in between the compression plates of the Universal Testing Machine and apply load gradually as shown in figure $3 \mathrm{a}, 3 \mathrm{~b} \& \mathrm{a}, 4 \mathrm{~b}$ The reading was noted at the time of first crack and at the time of failure.

2.3.1 Compressive strength test for cubes:

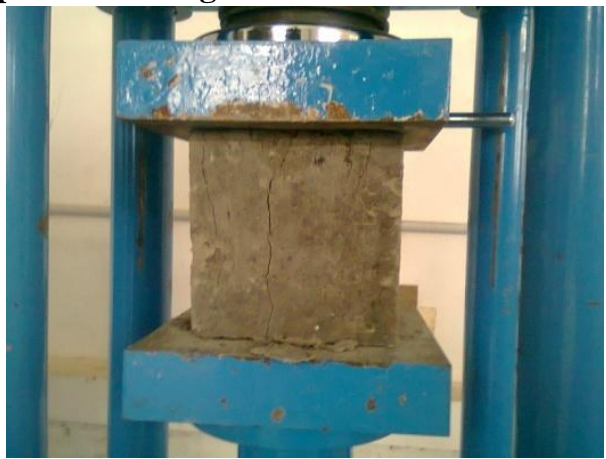

Figure 3a Testing of concrete cube specimen for compressive strength

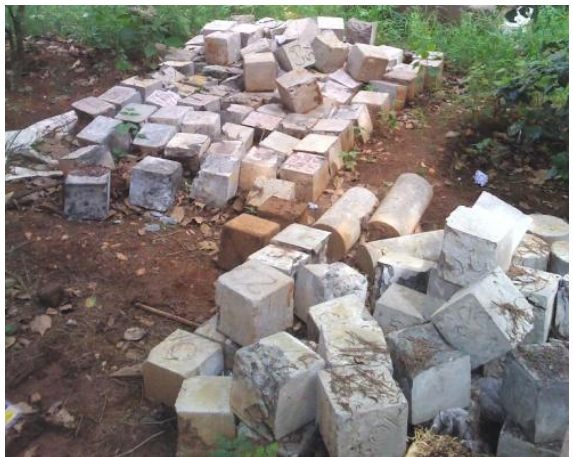

Figure 3b Failure mode of cube specimen in compressive strength 
2.3.2 Compressive strength test for cylinders:

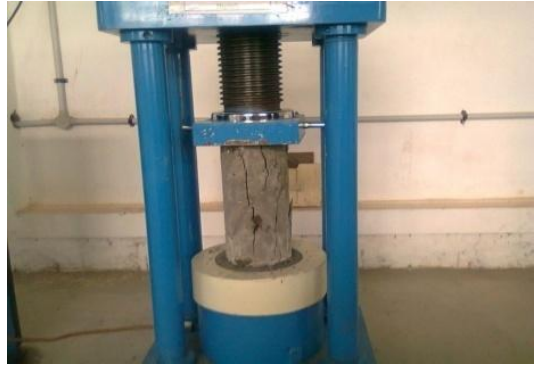

Figure 4a Testing of concrete cylinder specimen for compressive strength

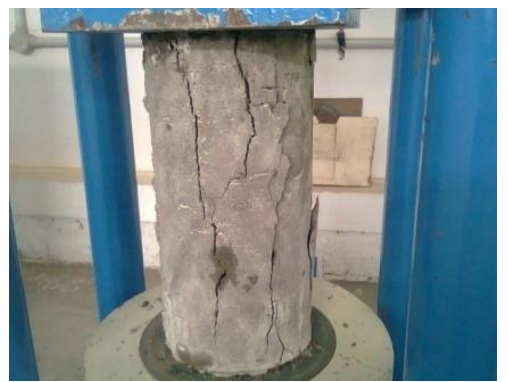

Figure 4b Failure mode of cylinder specimen in compressive strength

\subsection{Split tensile strength test:}

The prepared cylinders with the help of moulds and cured 28 days and 56days. At the end of curing period, the cylinders were placed in between the compression plates of the Universal Testing Machine and loaded gradually as shown in figure 5 The reading was noted at the time of first crack and at the time of failure.
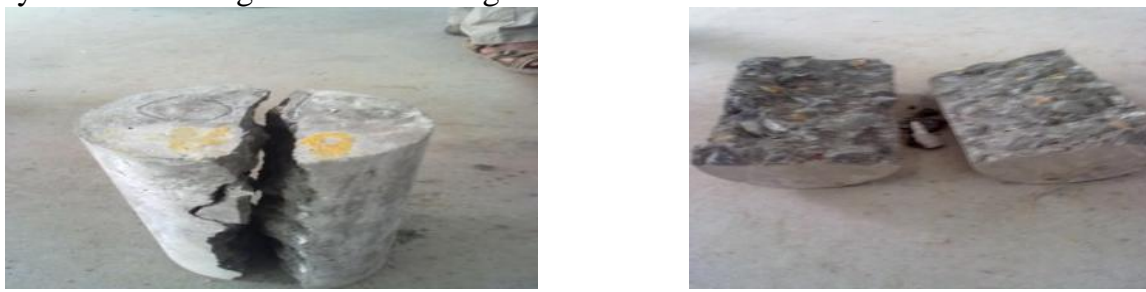

Figure 5 Failure mode of specimen in split tensile strength

\section{RESULTS AND DISCUSSION}

The development of strength (compressive and split tensile strength) with age for different replacement levels of metakaolin and $40 \%$ of quarry dust as a partial replacement of river sand with constant dosage of super plasticizers are as follows.

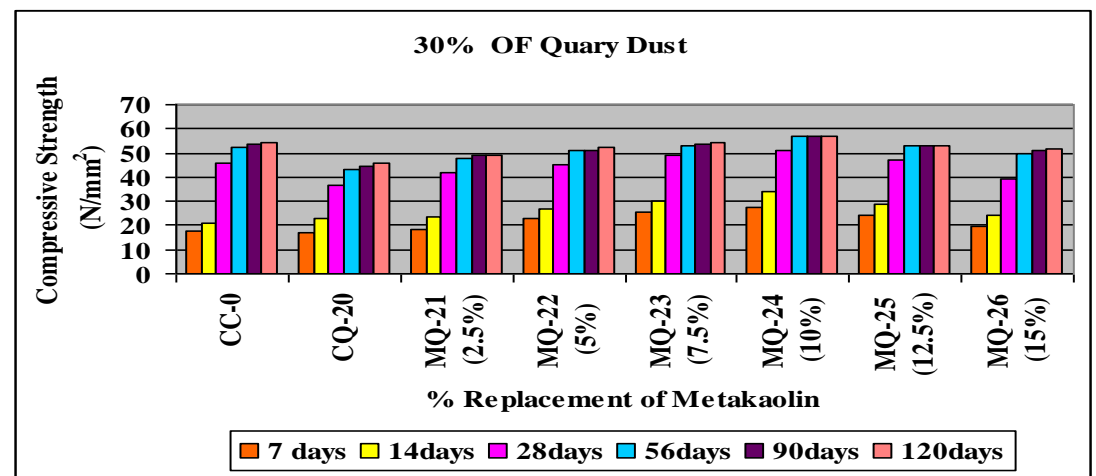

Fig- 6 7,14, 28,56,90 and 120 Days cube strength

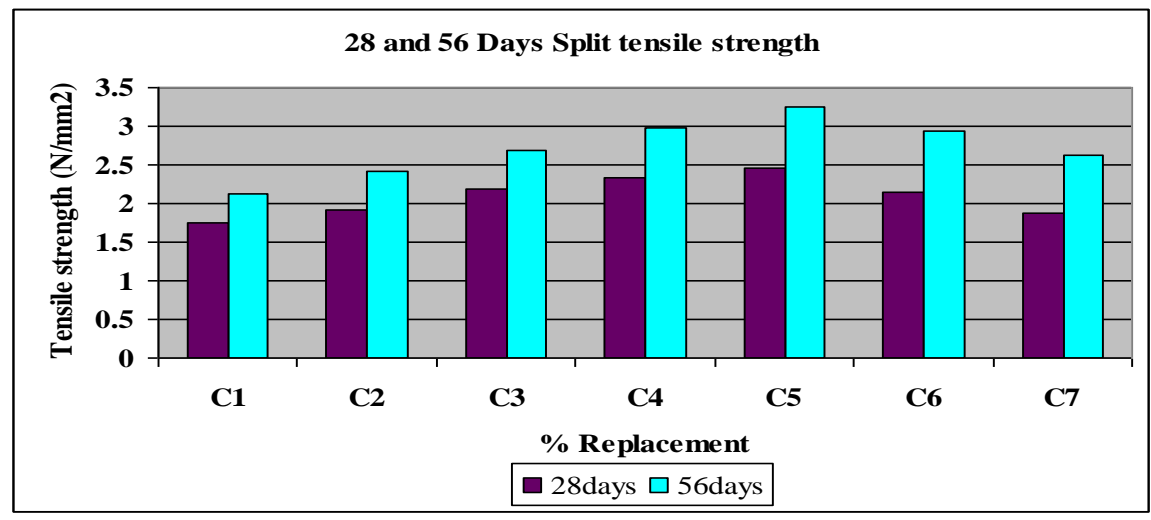

Fig-7- 28 and 56 Days Split tensile strength 


\section{CONCLUSIONS}

The present investigation shows that by the optimum percentage $(0,2.5,5,7.5,10,12.5 \& 15 \%)$ of Metakaolin as a partial replacement for cement together with partial replacement of natural river sand with quarry dust at $(0,10,20,30, \& 40)$,results in the production M40 grade mixes. The following conclusions can be derived based on the results and discussions above:

1. From the above experimental results it is proved that, Quarry Dust can be used as alternative material for the fine aggregate ( sand). And Metakaolin can be used as one of the alternative material for the cement used for producing HPC.. Based on the results the compressive and split tensile strengths are increased by mixing of Metakaolin with Quarry Dust.

2. The compressive strengths are $16 \%, 16 \% 10 \%, 10 \%, 10 \%$ and $10 \%$ at the period of $7,14,28,56,90$ and 120 days and the increase in the split tensile strength is $16 \%$ and $12 \%$ at the period of $28 \& 56$ days, by replacing $10 \%$ of cement with Metakaolin and 30\% of sand with Quarry Dust with 3\% Super Plasticizers

\section{REFERENCES}

[1] Murat M. Hydration reaction and hardening of calcined clays and related minerals: II. Influence of mineralogical properties of the raw-kaolinite on the reactivity of metakaolinite. Cement Concrete Res 1983;13:511-8

[2] Kou, S.C. and C.S. Poon, "Properties of concrete prepared with crushed fine stone, furnace bottom ash and fine recycled aggregate as fine aggregates", Construction and Building Materials, vol. 23, pp. 28772886, 2009.

[3] Celik, T. and K. Marar, "Effects of crushed stone dust on some properties of concrete", Cement and Concrete Research, vol. 26, pp. 1121-1130, July 1996.

[4] Wild, S., J.M. Khatib, and A. Jones, "Relative strength, pozzolanic activity and cement hydration in super plasticized metakaolin concrete", Cement and Concrete Research, vol. 26, pp. 1537-1544, Oct. 1996.

[5] Curcio, F., B.A. DeAngelis, and S. Pagliolico, "Metakaolin as a pozzolanic micro filler for high performance mortars", Cement and Concrete Research, vol. 28, pp. 803-809, June 1998.

[6] Poon, C. S., L. Lama, , S.C. Kou, , Y.L. Wong, and R. Wong, "Rate of pozzolanic reaction of metakaolin in high performance cement paste", Cement and Concrete Research, vol. 31 pp. 1301-1306, 2001.

[7] Ambroise J, Murat M, Pera J. Hydration reaction and hardening of calcined clays and related minerals. V - extension of the research and general conclusions. Cement Concrete Res 1985;15:261-8.

[8] Kumaran MK. Moisture diffusivity of building materials from water absorption measurements. J Therm Envelope Build Sci 1999;22:349-55.

[9] P.C. A"itcin, The durability characteristics of high performance concrete: a review, Cem. Concr. Compos. 25 (2003) 409-420.

[10] Weber, S.; Reinhardt, H.W. In Proceedings of the Fourth International Symposium on the Utilisation of High Strength/High Performance Concrete, Vol. 3, Paris, May 29 -June 3, 1996; de Larrard, F.; Lacroix, R., Eds.; 1996;pp 1295-1303.

[11] Oh J, Lee I, Kim J, Lee G. Application of neural networks for proportioning of concrete mixes. ACI Mat J 1999;96(1):61-7.

[12] Aitcin PC. The durability of high performance concrete. Proceedings of the one-day short course on concrete technology/HPC: Properties and Durability, University Malaya, Kuala Lumpur, May; 1997.

[13] Neville A, Aitcin PC. High-performance concrete - an overview. Materials and Structures 1998;31:1117.

[14] Islam MN, Zain MFM, Basri HB. Development of an expert system for high performance concrete mix design. Proceedings of the international conference on robotics, vision, information and signal processing, Penang, Malaysia, January, 2003.

[15] Mehta PK, Aitcin PC. Principles underlying production of highperformance concrete. Cem Conc Agg 990;12(2):70-8.

[16] Rougeron P, Aitcin PC. Optimisation of the composition of high performance concrete. Cem Conc Agg 1994;16(2):115-24. 